を吸収すべきではないか，答 逆である。我々は，患者のポジショ ニングや呼吸を軽視してきたきらいがある，反省すべきである。

演題293では，低感度で微粒子のノンクロスオーバーフィルムに 超高感度スクリーンを組み合わせたシステムと, 従来からのシステ 么の特性を比較し報告した。現像温度を変化させ，それぞれのシス テムで物理評価扔上び視覚評価を行っているが，これは大変な作業 であり，非常に貴重な資料である。演者は，現像温度が上昇して も，粒状性が非常に良いシステムであることから，被曝低減の可能 性を示哯している。しかし，一般の会員が臨床の現場で，このシス テムの持つ特性を生かすために，もう少し具体的な使用法について も言及して頂きたかった。

演題294は,新しく開発された,45秒現像処理対応のデュープフィ ルムについての発表である. 新しいフィルムは, 感度が低いため露 光時間が長くなるが, 広範囲の濃度域に扔いて, 従来のフィルムよ りも再現性が良い上報告した。質問 田㚼（奈良医大）視賞評価の 得点配分が等間隔でないのはなぜか。答 基準をうとし，等比級数 的に点数をつけた．質問 粟井（国循）べース濃度が高いが，再現 性に影響がないが.答 ベースの部分が多いマルチフォーマットカ メラのデューナ゚には，少し問題がある。

\section{画像工学 視覚評価（演題番号295～298）}

田畑洋二（奈良県立医科大学附属病院） このセクションは視覚心理に関する演題が 1 題, 観察環境に関す る演題が 2 題, 評洒法に関する演題が 1 題の合計 4 題からなる. 演題295は色彩心理学で論じられている枠の効果を画像のハード コピーにおいて検証した報告である。

枠の効果は染の太さなどにより同化と対比があるが，今回報告し た胸部 CT像に扔いては 1 枚の函像においても，枠とみなるものが 異なれば同化と対比の両方が斿こり，観察には注意が必要であると 報告した. 今後，このような効果が画像の評価や信号の検出能によ゙ の程度影響するのかまで言及していただきたい。

演題296はシャウカステンとフィルムの距離を変化させ，胸部を 想定した仮想病巣検出能を比較した。我々にはシャウカステンとフ イルムは密着して観察すべきものという先入観があるが，検討した 距離のなかでは $10 \mathrm{~cm}$ の場合が有意に検出能が高く興味深い結果 となっている。しかし，険出能とコントラストとの因果関係ははっ きりせず，他の因子が影響している可能性がある．また何らかの力 法で臨床画像を用いた検証を望卆，今後の研究に期待したい．

演題297は画像を観察するときのシャウカステンの照度と周辺照 度の影響についての報告である.周边照度の影䇾については検討し た範囲内において評価結果がよく一致し，影䇾はほとんどないとし ている。祐延 (大阪大) 上り評洒結果の一致は観察者の記境による ものではないかと質問があったが，できるだけ記憶できないよう に，観察時期や試料作成をしているとの回答があったまたシャウ カステン照度の影響については, 試料濃度によっては影響を受ける と報告している。本実験結果は実験に用いた照度の範囲内での結果 であることに注意すべきである。

演題298は階層分析法(AHPモデル)を胸部画像評価へ導入し， 最適システムの選定を試みた報告である.今回の発表は第う報であ るが，前回までとは部位別の画質を加味した点が異なる．辺見（泉 䗁村立）は，部位の項目に春椎を用いた理由を質問したが，演者よ りウエイトはゼロに近いが除外することはできないとの回答があ
った中前（奈良医大）はウエイトがゼロに近い場合は切り捨て， 他の項目のウエイトは基準化すべきではないかと質問したここのよ うな場合，ウエイトの決定が目的ならば除外すべきではないが，最 適システムの選定が目的ならば除外して問題はないと考える。また 星野（結核予防会）より結果に対してシステムの物理特性によって 検証しているのかと質問があった。演者から視覚的評価を信頼して いるので物理的評価は行っていないとの回答があったが，この手法 の妥当性を実証するためにも検証は必要であると考える。また今回 の発表では考慮されていなかったが, 各レベルでの項目の選定には AHP モデルでいう従属性を考慮しなければ正確な比率尺度を算出 することができないことや，項目間の独立性の問題などこの手法 の理論的背景を再検討していただきたい.

画像の評価，また機器および装置の評洒においても視覚評価が用 いられるようになってきた。しかし，試料の作成から人間の視覚特

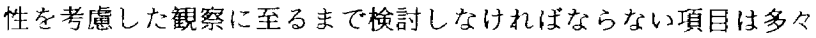
あるが，十分に検討されていない。したがって，視覚評価を行う際 の指針にするためにも本セクションは重要であり, 各演者のさらな る研究を期待したい。

画像工学 シネフィルム（演題番号299〜301）

天内 廣（横浜市立大学医学部附属病院） 本演題群は新製品シネフィルム“MI-CZ”に関する演題が 2 題 （演題299，301）と既存シネフィルムの画質評価に関する演題が 1 題 (演題300)である。

演題299は“MI-CZ”の開発の狙いと設計思想を述べ，粒状性や 鲜鋭性を良化させ高コントラスト化を計ったシネフィルムの新製 品を紹介した。相対感度は MI CG (=100) に対し55 (ソフナ一無 添加）と発表した。質問 (座長) ソフナー添加により $\mathrm{MI}-\mathrm{CZ}$ と MII-CG を同一 Gにした時, MI-CZ の画質上の有効性はでるか。答 両者の $\bar{G}$ を同一にした場合でも粒状性は向上し，脚部のコントラ ストは MI-CZの方が良い. 脚部以外では造影像の識別性は変わ的 ないと考えている．質問 中澤（昭和大）粒状性を良くすると鲜鋭 度が悪くなるように思うが，MI-CZ の鲜鋭度の向上には特別な技 術があるのか．答 鲜鋭度とコントラストには密接な関連がある。 コントラストの向上は情報の識別性（臨界点の見え易さ）を向上さ せるので, コントラストを上げたことが鲜鋭性も良くしていると考 えている。

演題301は“MI-CZ”をMI-CG と比較して䠛床評価したもので, その高コントラスト性が臨床使用で高く評価され粒状性や鲜鋭性 も MI-CG と同等と述へている. MI-CZ は冠状動脈造影に有用と 評価した。質問（座長）粒状性の榣床評価で MI-CGの方が良い 結果が示されているが, 物理的評価と反対の結果になっている。こ のことについてどのように考えているか. 答 医師 4 名と放射線技 師 3 名で臨床評価してもらった結果だが, 医師群は全員が臨床画像 全体の印象から MI-CGの方が粒状性が良いとし，技師群は全員が フィルムのもつ粒状性を評価して MI-CZ の方が良いと評価した ようである.評価実験前のプレゼンテーションに問題があったのか もしれないと考えている。

演題301は既存シネフィルム (CFJ，CFL，VARICATH-II）に おける低濃度領域の血管描出能に関する研究で, 感度差を現像処理 によって補正し，心筋濃度をほぼ同一にして低濃度領域のコントラ スト分解能や微細血管描出能を比較している。結果は, 特性曲線で 